\title{
Regulated Secretion of $\beta$-Amyloid Precursor Protein in Rat Brain
}

\author{
Steven A. Farber, ${ }^{1}$ Roger M. Nitsch,, ${ }^{1,2, a}$ Joachim G. Schulz, ${ }^{1}$ and Richard J. Wurtman' \\ 'Department of Brain and Cognitive Sciences, Massachusetts Institute of Technology, Cambridge, Massachusetts \\ 02139 and ${ }^{2}$ Department of Neurology, Massachusetts General Hospital and Harvard Medical School, Boston, \\ Massachusetts 02114
}

The $\beta$-amyloid precursor protein (APP) is a ubiquitous, highly conserved secretory glycoprotein that is expressed at high levels in mammalian brain by neurons, astrocytes, and activated microglia. Secreted APP (APPs) is generated by the cleavage of APP within the $\beta$-amyloid $(A \beta)$ portion of its ectodomain. The formation and secretion of APPs can be increased by activation of particular neurotransmitter receptors and subsequent protein phosphorylation. We found that tissue slices from rat cortex, hippocampus, striatum, and cerebellum secrete APPs in vitro. APPs secretion was enhanced by electrical stimulation, but was not associated with a general increase in the release of total protein, lactate dehydrogenase (LDH) activity, or neuronal cell adhesion molecules. The pharmacological profile of stimulation-induced APPs secretion suggests complex interactions between muscarinic receptor subtypes in the tissue slices: in the unstimulated state, activation of Muscarinic $M 1$ receptors increased APPs release while nonspecific activation of multiple muscarinic receptors had little effect on APPs release; in electrically stimulated slices, nonspecific inhibition of muscarinic receptors blunted the increase in APPs secretion. The nonspecific muscarinic agonist carbachol increased APPs secretion only in the presence of an $M 2$ receptor antagonist, suggesting that actlvation of $M 2$ receptors suppresses APPs formation. These data indicate that secretory APP processing in brain includes depolarization-enhanced cleavage of the cell-associated holoprotein within its ectodomain, and that the net effect of depolarization involves several subtypes of acetylcholine receptors.

[Key words: $\beta$-amyloid precursor protein (APP), amyloid, brain slices, protein secretion, electrical stimulation, acetylcholine, muscarinic receptors, Alzheimer's disease]

APP and APP-like proteins (APLP) are homologous secretory glycoproteins with a single transmembrane domain, an $\mathrm{N}$-terminal ectodomain and an intracellular C-terminal region (Kang

\footnotetext{
Received Apr. 10, 1995; revised July 11, 1995; accepted July 14, 1995.

We thank John H. Growdon for useful discussions, Dennis Selkoe and Sangram Sisodia for providing antibodies, and Rudi Hammer for WAL 2014. This work was supported by grants from the National Institutes of Mental Health ( $\mathrm{MH}-28783$ ), the National Institute on Aging (P-50-AG-05432), and the Center for Brain Sciences and Metabolism Charitable Trust. R.N. received a Hoffman Fellowship in Alzheimer's disease from the Massachusets General Hospital.

Correspondence should be addressed to Dr. R. J. Wurlunall, Departintent of Brain and Cognitive Sciences, Massachusetts Institute of Technology, E25-604, 77 Massachusetts Avenue, Cambridge, MA 02139-4307.

Present address: Center for Molecular Neurobiology, University of Hamburg, UKE 22, Martinistrasse 52, 20246 Hamburg, Germany.

Copyright (C) 1995 Society for Neuroscience 0270-6474/95/157442-10\$05.00/0
}

et al., 1987; Tanzi et al., 1987; Kitaguchi et al., 1988; Ponte et al., 1988; Wasco et al., 1992, 1993; Slunt et al., 1994). These proteins are ubiquitously expressed, highly conserved, developmentally regulated, and found in especially high levels within the brain. APl is the only member of this gene family that contains an amyloid $\beta$ protein $(A \beta)$ domain and can thus give rise to amyloidogenic derivatives that might polymerize to form the brain amyloid characteristic of Alzheimer's disease (AD) (reviewed by Selkoe, 1994).

The functions of $\Lambda \mathrm{PP}$ and its secretory derivatives (Weide mann et al., 1989) are not well understood, but some evidence suggests that they may have neurotrophic (Milward et al., 1992; Mucke et al., 1994) and neuroprotective activities (Mattson et al., 1993). Secreted APPs can also promote cell adhesion (Schubert et al., 1989; Koo et al., 1993) and regulate the activities of extracellular proteinases (Van Nostrand et al., 1990; Sinha et al., 1991). In contrast, $A \beta$ peptides can be toxic (Behl et al., 1994). APP-deficient mice fail to display striking pathologies but do exhibit reactive gliosis, decreased body weight, and reductions in locomotor activity and forelimb grip strength (Zheng et al., 1995). Mice expressing a shorter form of APP that lacks an $\mathrm{N}$-terminal domain encoded by exon 2 exhibit learning and memory deficits and an increase in the prevalence of corpus callosum agenesis (Müller et al., 1994). Transgenic mice overexpressing the $717 \mathrm{Val} \rightarrow$ Phe variant of APP can display brain amyloid deposits resembling those found in Alzheimer's disease (Games et al., 1995).

Proteolytic cleavage of APP to yield nonamyloidogenic APP and potentially amyloidogenic $A \beta$ peptides (Haass et al., 1992; Gabuzda et al., 1993) is regulated through complex mechanisms (Nitsch et al., 1992; Busciglio et al., 1993; Buxbaum et al., 1993; Hung et al., 1993) that involve activation of various cell surface receptors coupled to protein kinases. For example, APP* secretion is accelerated by agonists for M1 or M3 muscarinic receptors, as well as by activation of protein kinase $\mathrm{C}$ (Buxbaum et al., 1990, 1992; Nitsch et al., 1992; Slack et al., 1993) or by treatments that increase net tyrosine phosphorylation (Slack et al., 1995). Increases in APP secretion are associated with reductions in $A \beta$ in many cell culture systems, suggesting a reciprocal relationship between the processing of APP into either APP or A $\beta$ (Busciglio et al., 1993; Hung et al., 1993; Buxbaum et al., 1994). The brain proteinases involved in these processing events have not been isolated, but are classified according to their site of cleavage. $\alpha$-Secretase cleavage occurs between position 16 and 17 within the $A \beta$ domain (Esch et al., 1990; Sisodia et al., 1990; Sisodia, 1992); $\beta$-secretase cleavage occurs at the $N$-terminus of the $A \beta$ domain (Seubert et al., 1993); and $\gamma$-secretase cleavage occurs at the $C$-terminus of $A \beta$, within the 
membranc-spanning domain. Thus, $\alpha$-sccretase activity precludes the formation of brain amyloid from APP whereas $\beta$ - and $\gamma$-secretase activities can generate $A \beta$ and therefore can give rise to amyloid formation.

In freshly prepared slices from mammalian brain, regulated APPs secretion correlate: with the frequency of externally applied electrical pulses, and is dependent on the formation of action potentials (Nitsch et al., 1993). The present studies used this slice system to study the pharmacology of APP release from brain tissues. We found that APP was secreted at a basal rate from brain cortex, striatum, hippocampus, and cerebellum. APPs secretion was increased by electrical stimulation in all brain regions and was apparently independent of phosphatidylinositol (PI)-mediated signaling. APP" secretion was also increased by inhibition of muscarinic $\mathrm{M} 2$ receptors as well as by stimulation of $\mathrm{M} 1$ receptors. These findings suggest a complex interaction of individual muscarinic receptor subtypes in the regulation of APP processing in mammalian brain.

\section{Materials and Methods}

Animals, tissues, and superfusion system. Adult Sprague-Dawley rats (Charles River, Cambridge, MA) weighing 350-700 gm, were exposed to a $12 \mathrm{~L}: 12 \mathrm{D}$ cycle and were treated in accordance with the guidelines established by the MIT Committee on Animal Care. Animals were anesthetized with ketamine $(85 \mathrm{mg} / \mathrm{kg}$ body weight i.m.) and decapitated in a cold room $\left(+4^{\circ} \mathrm{C}\right)$. Brains were rapidly placed in chilled $\left(+4^{\circ} \mathrm{C}\right)$ physiologic buffer (in mM: $120 \mathrm{NaCl}, 3.5 \mathrm{KCl}, 1.3 \mathrm{CaCl}_{2}, 1.2 \mathrm{MgSO}_{4}, 1.2$ $\mathrm{NaH}_{2} \mathrm{PO}_{4}, 25 \mathrm{NaHCO}_{3}, 10$ glucose, insufflated with $95 \% \mathrm{O}$ and $5 \%$ $\left.\mathrm{CO}_{2}\right)$. The dissection buffer contained ketamine $(1 \mathrm{mM})$ to reduce excitotoxicity during the dissection and slice preparation procedures $(\mathrm{Ol}-$ ney et al., 1986). Meninges and blood vessels were carefully removed and individual brain regions were cut at $+4^{\circ} \mathrm{C}$ into $300 \mu \mathrm{m}$ slices by using a Mcllwain tissue chopper (Mickle Laboratory Engineering Co., Gomstall, Surrey, U.K.). Slices were washed with cold buffer three times to remove debris, three to six slices were transferred to stimulation chambers (Warner Instrument Corp., Hamden, CT), and were superfused $(0.8 \mathrm{ml} / \mathrm{min})$ at $+37^{\circ} \mathrm{C}$ for $50-75 \mathrm{~min}$ prior to the stimulation experiments. Electrical depolarization was performed by using a polarity reversal stimulator (Warner Instrument Corp.) that monitors chamber resistance. Maximal electrical stimulation parameters were $125 \mathrm{~mA}, 1.0$ msec pulse duration, and $30 \mathrm{~Hz}$, resulting in a current density of 4.95 $\mathrm{mA} / \mathrm{min}^{2}$ ard requiring 30-40 V. WAL 2014 (Ensinger et al., 1993) was obtained from Boehringer Ingelheim; other reagents were obtained from Sigma.

Preparation of protein extracts. Analyses of specific tissue proteins were performed on aliquots of protein extracts obtained from homogenized slices. These were removed from the chambers, chilled, pelleted, and proteins were extracted in $500 \mu \mathrm{l}$ lysis buffer $(0.1 \mathrm{M}$ Tris $\mathrm{pH} 6.8$, $15 \%$ glycerol, 5 mM EDTA, $2 \%$ SDS, $2 \%$ Triton X-100, 2 mm phenylmethylsulfonyl fluoride, $10 \mu \mathrm{g} / \mathrm{ml}$ aprotinin, $1 \mu \mathrm{g} / \mathrm{ml} \mathrm{TLCK}, 1 \mu \mathrm{g} / \mathrm{ml}$ leupeptin, and $0.1 \mu \mathrm{g} / \mathrm{ml}$ pepstatin) and sonicated. Aliquots were frozen and stored at $-70^{\circ} \mathrm{C}$ until being subject to Western blot analyses. Slices assayed for tissue LDH activity were homogenized in $1 \mathrm{ml}$ of chilled Krebs-Ringer buffer and sonicated. Several aliquots were rapidly frozen and stored at $-70^{\circ} \mathrm{C}$.

Purification of secreted proteins from superfusates. After a 50-75 min equilibration period, superfusates were collected on ice and phenylmethylsulfonyl fluoride (PMSF, $250 \mu \mathrm{M}$ ) was added from a $100 \mathrm{~mm}$ isopropanol stock. Superfusate media were centrifuged for $30 \mathrm{~min}$ at $10,000 \times g$ at $+4^{\circ} \mathrm{C}$ to remove debris. Supernatants were subjected to ultrafiltration against water at $+4^{\circ} \mathrm{C}$ by using cellulose dialysis tubing with a molecular mass cut-off of 12 to $14 \mathrm{kDa}$ and by applying a negative pressure of 320 torr. A concentrated protein solution of $4 \mathrm{ml}$ was frozen, dried by vacuum centrifugation, and reconstituted in gel loading buffer ( $125 \mathrm{~mm}$ Tris $\mathrm{pH} 6.8,4 \%$ SDS, $20 \%$ glycerol, $5 \%$ mercaptoethanol, $0.3 \%$ bromophenol blue). Alternatively, chilled superfusates were centrifuged and blotted directly onto polyvinyldifluoride membranes (Immobilon. Waters) by vacuum filtration in the absence of PMSF To solubilize immobilized proteins, the filters were incubated at $+50^{\circ} \mathrm{C}$ for $20 \mathrm{~min}$ in $70 \%$ isopropanol and $2 \%$ triflouroacetic acid in a shaking water bath, dried by vacuum centrifugation, and reconstituted in gel loading buffer. Both concentration protocols yielded comparable results.

Western blotting. Reconstituted superfusate proteins were boiled for $3 \mathrm{~min}$, and amounts equivalent to $600 \mu \mathrm{g}$ total slicc protein were subjected to electrophoresis on continuous $12 \%$ SDS-polyacrylamide mini gels, electroblotted onto polyvinyldifluoride membranes. Remaining binding sites were blocked with $1 \%$ nonfal dry milk (Carnation), and probed with primary antibodies. We used the monoclonal antibody 22C11 (Weidermann et al., 1989), the polyclonal antiserum anti-C8 (Selkoe et al., 1988), the polyclonal antiserum R 1736 (Podlisny et al., 1991), or the monoclonal antibody anti-N-CAM (Sigma). The secondary horseradish peroxidase-linked antibodies (Amersham) were visualized by enhanced chemiluminescence (Amersham) using Kodak x-ray films. Linearity of the immunoreaction was assured by serial dilution curves and by preflashing the films prior to exposure to the chemiluminescent products. Immunoreactive bands were compared by densitometry with a laser scanner (Pharmacia LKB UltroScan XL) set at 40 $\mu \mathrm{m}$ vertical interval size and $2.4 \mathrm{~mm}$ horizontal slit width. Typically, superfusion media obtained from slices from one animal were analyzed in duplicate. Superfusion chambers were run in parallel for both control and trearment conditions. Groups used for statistical comparisons were always compared within the same Western blot. Results of duplicate measurements were averaged, normalized to the control values, and used as one individual data point for statistical analyses. Data were compared statistically by analysis of variance and post hoc NewmanKeuls tests.

Neurotransmitter and lactate dehydrogenase (LDH) assays. Acelylcholine in the superfusates was separated from other secreted cholinecontaining compounds by reverse-phase HPLC and exposed to a postcolumn reactor containing immobilized acetylcholinesterase and choline oxidase (ESA). Oxidized products were detected electrochemically by a platinum electrode $(300 \mathrm{mV}$ ) (Coulochem II, ESA) and quantitated by comparison to known amounts of freshly dissolved acetylcholine. For the determination of secreted glutamate and aspartate, $0.9 \mathrm{ml}$ of superfusion media were concentrated by anion exchange chromatography (AG 1-X8, formate form; BioRad), eluted with $0.3 \mathrm{~N}$ formic acid, dried by vacuum centrifugation, and reconstituted in $90 \mathrm{~mm} \mathrm{NaHCO}_{3}$, $\mathrm{pH}$ 8.0. Reconstituted amino acids were derivatized with 9-fluorenylmethyl chloroformate $(2 \mathrm{mM})$ in dried acetone, and separated by reverse-phase HPLC (Rainin, Microsorb C-18). Derivatives were detected by fluorometry and quantitated by comparison to standard concentration analyzed in parallel. LDH activity in $0.5 \mathrm{ml}$ superfusates and $2.0 \mu \mathrm{l}$ of tissue homogenate was assayed by using a commercially available assay kit (Sigma No. 500).

PI turnover assays. Tissue slices were equilibrated in superfusion chambers for $30 \mathrm{~min}$ at $+37^{\circ} \mathrm{C}$; transferred to glass tubes; and isotopically labeled with $5 \mu \mathrm{Ci} / \mathrm{ml}^{3} \mathrm{H}$-myo-inositol (DuPont-NEN) using calcium-free Krebs-Ringer buffer in a Dubnoff metabolic shaker, maintained at $+37^{\circ} \mathrm{C}$ for $30 \mathrm{~min}$, and kept under a $95 \%$ oxygen and $5 \% \mathrm{CO}_{2}$ atmosphere. Buffer containing labeled inositol was replaced with fresh buffer after $15 \mathrm{~min}$. Slices were washed three times in calcium-free buffer and returned to the superfusion chambers. To block recycling of radiolabeled inositol phosphate, lithium chloride $(10 \mathrm{~mm})$ was added to the superfusion medium after $4 \mathrm{~min}$. Simultaneously, the $\mathrm{NaCl}$ concentration was reduced to maintain a constant osmolarity of $300 \mathrm{mOs}$, as verified osmometrically. After $8 \mathrm{~min}$, slices were exposed to drugs and/ or electrical stimulation for $20 \mathrm{~min}$. Slices were removed from the chambers, homogenized in $1 \mathrm{ml}$ of buffer ( $10 \mathrm{~mm}$ Hepes, $\mathrm{pH} 7.4$ ) using a glass-teflon homogenizer. The homogenizer was rinsed with $1 \mathrm{ml}$ of methanol, which then was added to the mixture. After removing an aliquot for protein assay, $2 \mathrm{ml}$ of chloroform were added to the mixture to extract the lipid components. The upper and lower phases were separated after centrifugation $(1500 \times \mathrm{g}, 15 \mathrm{~min})$, and ${ }^{3} \mathrm{H}$-inositol containing lipids in the organic phase were determined using scintillation spectrometry. The aqueous phase of the lipid extraction system was applied to anion exchange chromatography column ( $A G$ 1-X8, formate form; BioRad), and free inositol was removed by rinsing with $10 \mathrm{ml}$ water. Radioactive inositol phosphates were eluted with a $5 \mathrm{ml} 1 \mathrm{M}$ ammonium formate and $0.1 \mathrm{M}$ formic acid, and quantified using liquid scintillation spectrometry. Superfusion media obtained during incubation of the slices were analyzed in parallel for secreted APP.

\section{Results}

$A P P$ secretion is enhanced by electrical depolarization and modulated by muscarinic receptors

Electrical field stimulation $(30 \mathrm{~Hz}, 100 \mathrm{~mA}$ and pulse duration of $1 \mathrm{msec}$ ) of rat brain slices significantly increased APP release 
A.

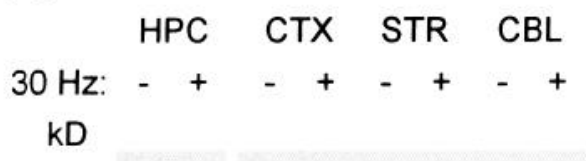

200-

97-

69-

46-

$30-$

21-

lane:

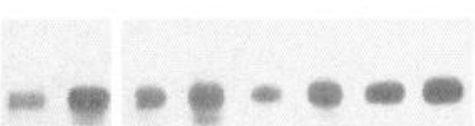

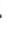

. 列

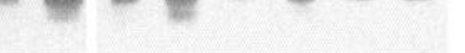

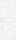

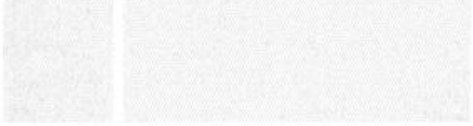

$\begin{array}{lllllllll}1 & 2 & 3 & 4 & 5 & 6 & 7 & 8\end{array}$
B.

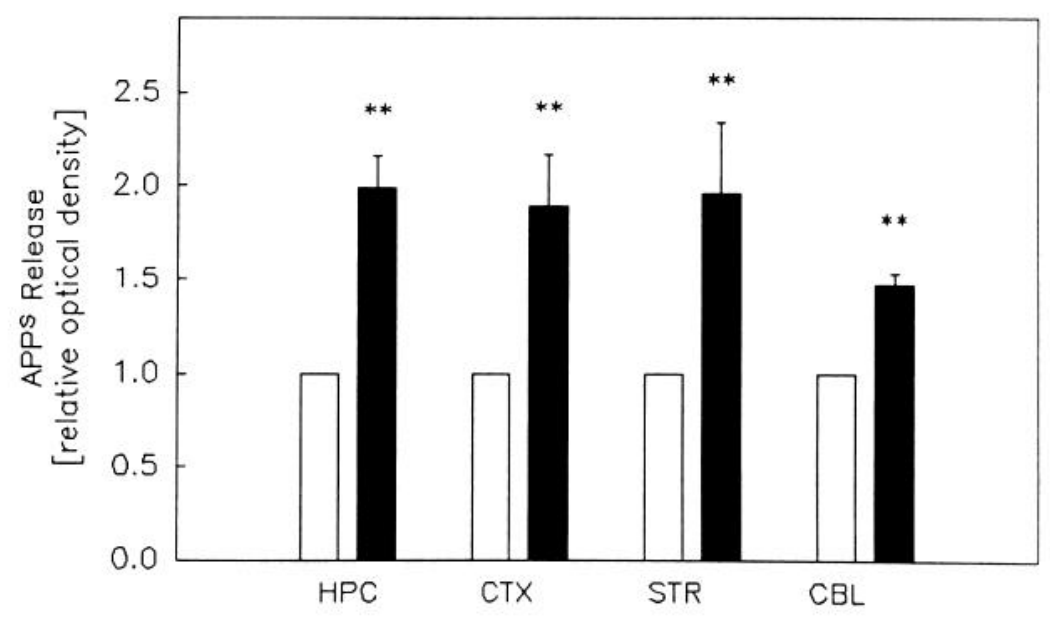

Figure 1. APP is secreted from slices of rat cortex, striatum, hippocampus, and cerebellum. Rat brain slices were equilibrated in superfusion chambers for $50 \mathrm{~min}$, and then stimulated $(30 \mathrm{~Hz}$ at $1 \mathrm{msec}$ pulse duration) for an additional $50 \mathrm{~min}$. A. Superfusion media collected during this interval were concentrated by ultrafiltration and analyzed by immunoblot. Secreted N-terminal APP derivatives were visualized after probing with the $22 \mathrm{C} 11$ antibody. $B, A P P$ release from each region was quantified by densitometry and normalized to unstimulated controls. Data are means \pm SEM from 8 (HPC), 4 (CBL), 7 (CTX; STR) experiments. ${ }^{*} p<0.01$ versus respective unstimulated control. $H P C$, hippocampus, $C B L$, cerebellum; $C T X$, cortex; and STR, striatum.

in all regions examined (Fig. $1 A$ ). Consistent with previous studies, APP' release was doubled in hippocampal slices (Nitsch et al., 1993); however, release was also enhanced by electrical stimulation in cortical, striatal and cerebellar slices (Fig. $1 B$ ). In subsequent experiments, cortical and/or hippocampal slices were superfused with various pharmacologic agents to assess the roles of muscarinic receptors in regulating brain APPs release. Coadministration of gallamine $(50 \mu \mathrm{M})$, a M2 antagonist, with carbachol $(100 \mu \mathrm{M})$, a nonspecific muscarinic agonist, significantly increased APP secretion from unstimulated slices $(162 \pm 25 \%$ increase over controls; $p<0.01$ ) (Fig. 2A). Carbachol alone had no significant effect on APP' secretion, and gallamine alone increased basal APP` release by $88 \pm 17 \%(p<0.02)$. Exposing slices to atropine $(1 \mu \mathrm{M})$, a general muscarinic antagonist, inhibited the APPs release evoked by electrical stimulation by 78 $\pm 5 \%(p<0.01)$. The muscarinic agonist WAL 2014 increased resting APP release by $100 \%(p<0.05)$ at a concentration of $1 \mu \mathrm{M}$; however, higher doses $(>70 \mu \mathrm{M})$ lacked this effect (Fig. $2 B$ ). The biphasic nature of the WAL 2014 effect was predicted from the fact that the drug acts with relative specificity on $\mathrm{ml}$ and $\mathrm{m} 3$ receptor subtypes at low concentrations, but also stimulates $\mathrm{m} 2$ and $\mathrm{m} 4$ receptors at higher concentrations. Nonspecific activation of all muscarinic receptors with carbachol failed to enhance APPs release from hippocampal slices, at any concentration tested (Fig. 2C).

\section{Electrical depolarization increases neurotransmitter release}

Samples of superfusates were analyzed for various neurotransmitters using HPLC. Increased release of acetylcholine and glutamate provided evidence that the electrical stimulation had effectively depolarized neurons within the slice. Consistent with our previous findings (Nitsch et al., 1993), electrical stimulation increased acetylcholine release to $531 \pm 114 \%$ of basal levels by stimulation $(p<0.05)$, and this effect was inhibited by the sodium channel antagonist tetrodotoxin $(1 \mu \mathrm{M})$ (Fig. $3 A)$. Elec- trical stimulation also evoked glutamate release from all brain regions tested (Fig. 3B): glutamate release was approximately $2.0 \mathrm{nmol} / \mathrm{mg} / \mathrm{hr}$ in all regions; this increased to $15.9 \pm 2.8 \mathrm{nmol} /$ $\mathrm{mg} / \mathrm{hr}(p<0.01), 6.5 \pm 0.9 \mathrm{nmol} / \mathrm{mg} / \mathrm{hr}(p<0.01), 9.7 \pm 1.9$ $\mathrm{nmol} / \mathrm{mg} / \mathrm{hr}(p<0.01)$, and $32.3 \pm 2.9 \mathrm{nmol} / \mathrm{mg} / \mathrm{hr}(p<0.01)$ in hippocampus, cortex, striatum, and cerebellum, respectively. Aspartate release was increased in media from hippocampa but not cortical slices $(p<0.05)$ (Fig. $3 C)$.

\section{Electrical stimulation does not cause nonspecific protein release}

Stimulation had no effect on total protein release: typically 25 $50 \mu \mathrm{g}$ was released per $\mathrm{mg}$ total protein during a $50 \mathrm{~min}$ collection period, whether or not stimulation was applied. Examination of individual proteins by coomassie blue staining, after separation by SDS polyacrylamide gels, also revealed no obvious differences between secreted proteins recovered from stimulated and control slices (Fig. 4A). To address possible effects of electrical field stimulation on other intrinsic membrane proteins besides APP, Western blots of secreted proteins were probed with antibodies to N-CAM, a 120-220 kD neural cell adhesion molecule existing in various isoforms derived from alternative splicing of RNA. Both APP and N-CAM have large extracellular $\mathrm{N}$-terminal domains that include a heparin-binding domain, a single membrane-spanning domain, and a short cytoplasmic C-terminus (Jessell, 1988). As expected, N-CAM was abundant in protein extracts prepared from the slices; however, it was undetectable in the concentrated superfusation media obtained after stimulation of slices from any of the brain regions (Fig. $4 B$ ). This finding was verified by concentrating secreted proteins by ultrafiltration through cellulose, and by slot blotting followed by elution from PVDF membranes.

Release of the cytosolic enzyme LDH was also used as an index of cell integrity and viability (Koh and Choi, 1987). LDH activity was assayed in superfusion fluids from hippocampal 
A.

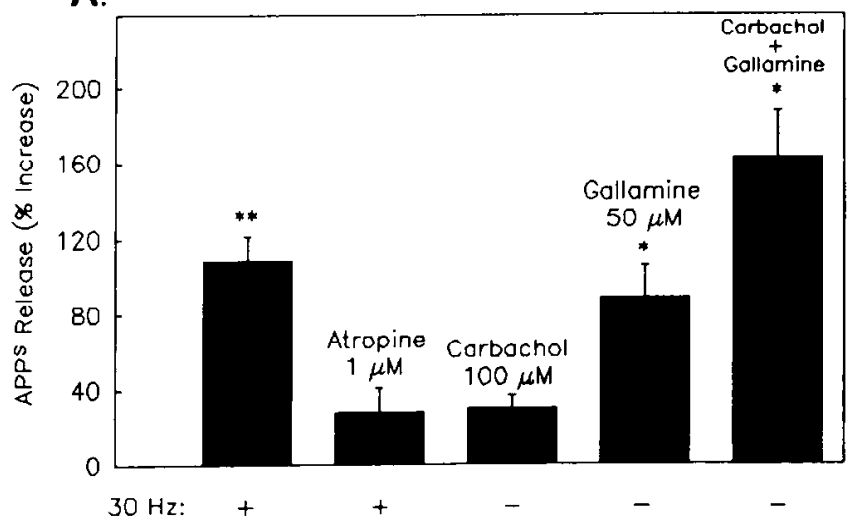

B.

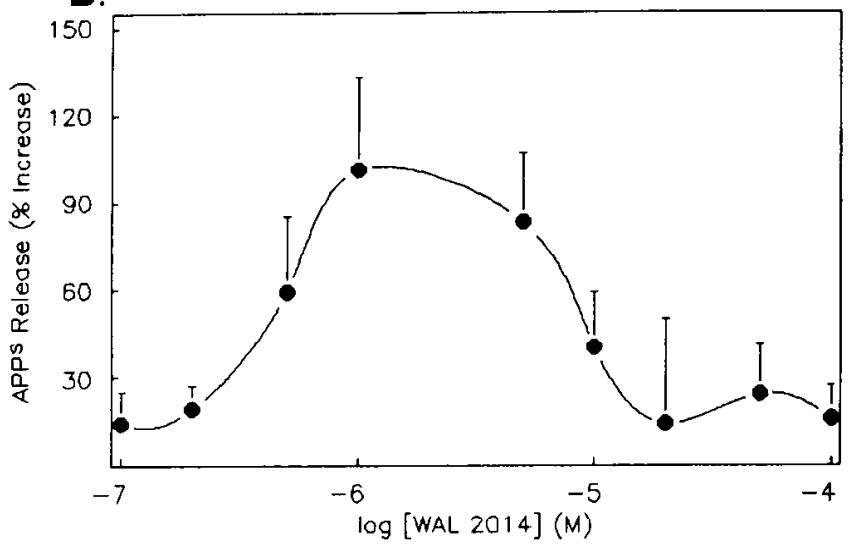

C.

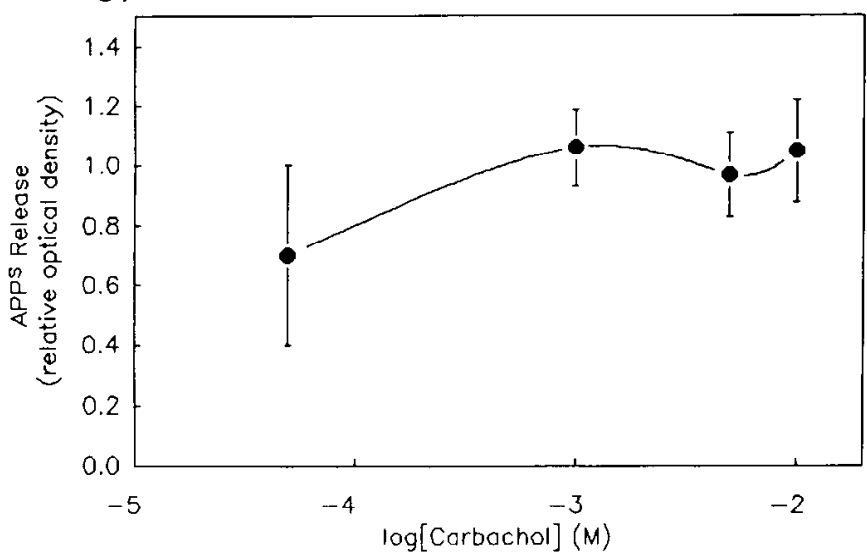

Figure 2. Effects of muscarinic agents on stimulation-induced APP secretion. Slices were equilibrated for $75 \mathrm{~min}$, then exposed to drugs for $20 \mathrm{~min}$. Data represent the percentage increases in APP release, compared with that from unstimulated control slices during a 20 min period of drug exposure. $A$. Slices in parallel chambers were subjected to electrical stimulation $(30 \mathrm{~Hz})$ as a positive control. The muscarinic antagonist atropine $(I \mu \mathrm{M})$ inhibited this increase but the nonspecific agonist carbachol failed to mimic it unless presented with gallamine, an $M 2$ receptor antagonist. Data are means \pm SEM from four to eight experiments. B, A more selective Ml agonist (WAL 2014) enhanced APP release from cortical slices at low concentrations. $C$, The nonspecific muscarinic agonist carbachol had no effect on APP release from hippocampal slices. APP was collected over a $50 \mathrm{~min}$ interval after a $50 \mathrm{~min}$ equilibration period. Data are means \pm SEM from three to six experiments at each dose.
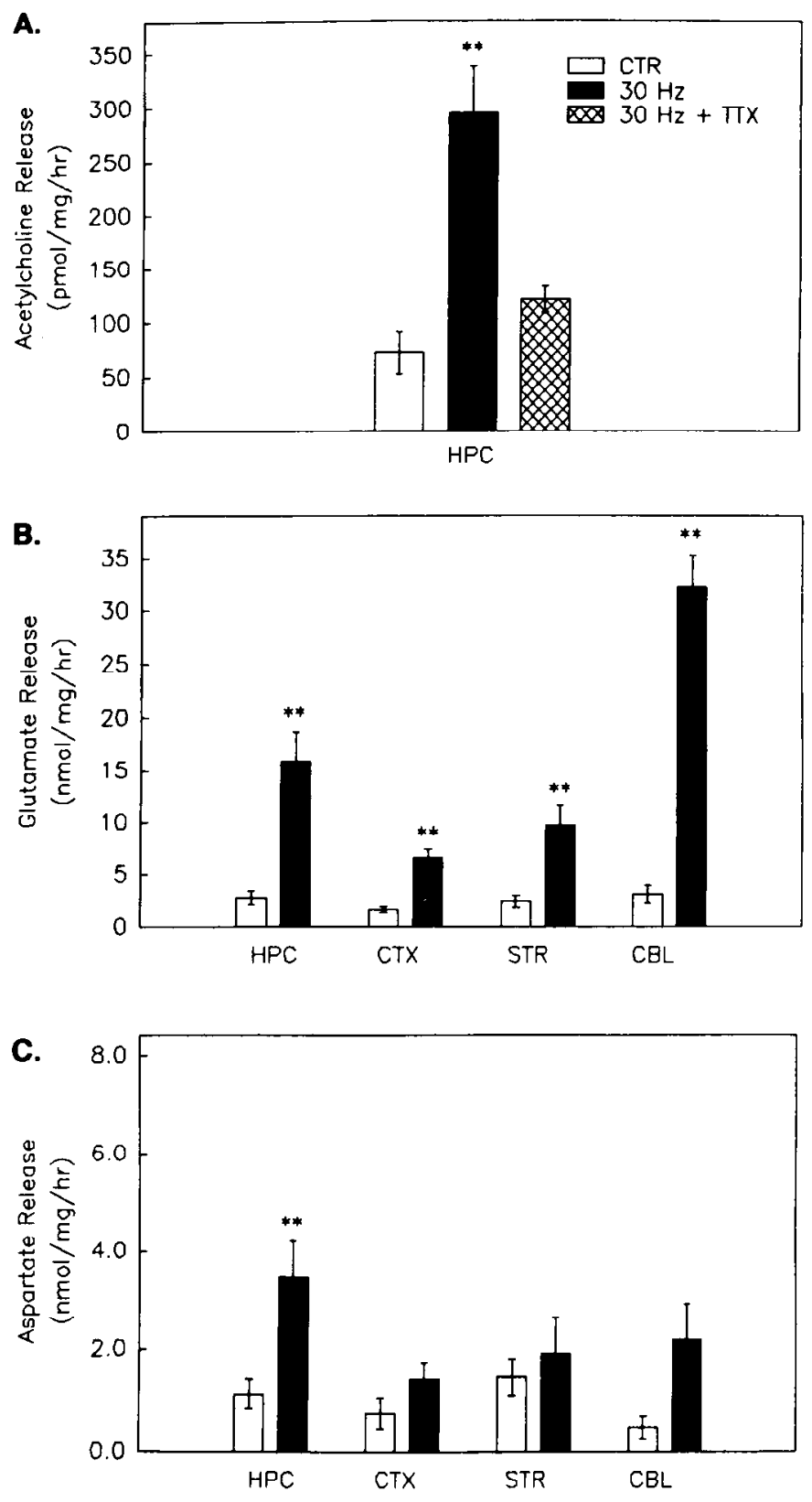

Figure 3. Electrical stimulation enhances acetylcholine and glutamate release from brain slices. Neurotransmitter release was assayed in aliquots of superfusion media by HPLC. $A$. Acetylcholine release was enhanced fourfold from stimulated hippocampal slices and this increase was blocked by tetrodotoxin $(1 \mu \mathrm{M})$. Data are expressed as percents of basal release and represent means \pm SEM of five experiments. ${ }^{*} p<$ 0.05 . $B$, Glutamate release from all brain regions was increased threeto ninefold by stimulation. $C$, Aspartate release was increased only in hippocampal slices. Data are means \pm SEM from 8 (HPC), 4 (CBL), 7 (CTX; STR) experiments. ${ }^{*} p<0.01$ versus respective unstimulated control. $H P C$, hippocampus, $C B L$, cerebellum; $C T X$, cortex; and STR, striatum.

slices collcctcd for a $2 \mathrm{hr}$ period beginning immediately following loading of the superfusion chamber. Considerable LDH activity was released immediately after slice preparation; however, its activity in the medium decreased steadily during the equilibration interval, reaching a stable baseline after 50 to $60 \mathrm{~min}$ (Fig. $4 C$ ), which was unaffected by electric field stimulation (Fig. 4D). 
A.

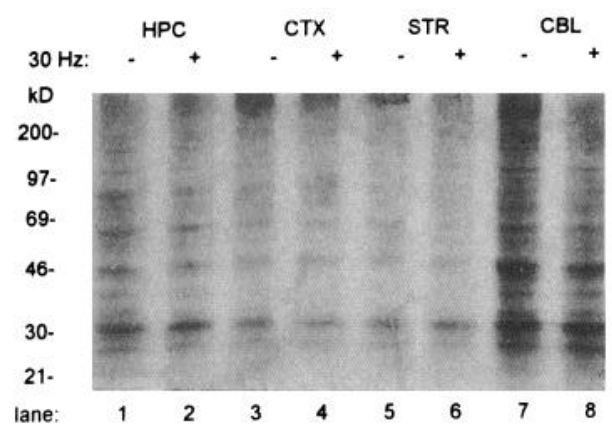

B.

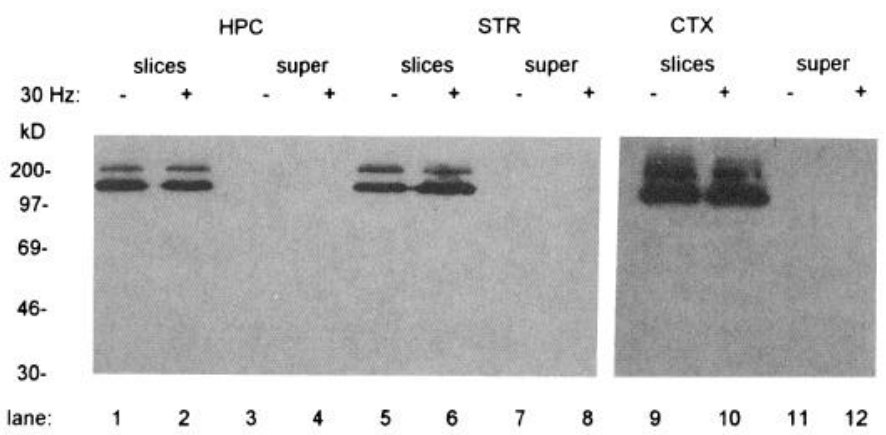

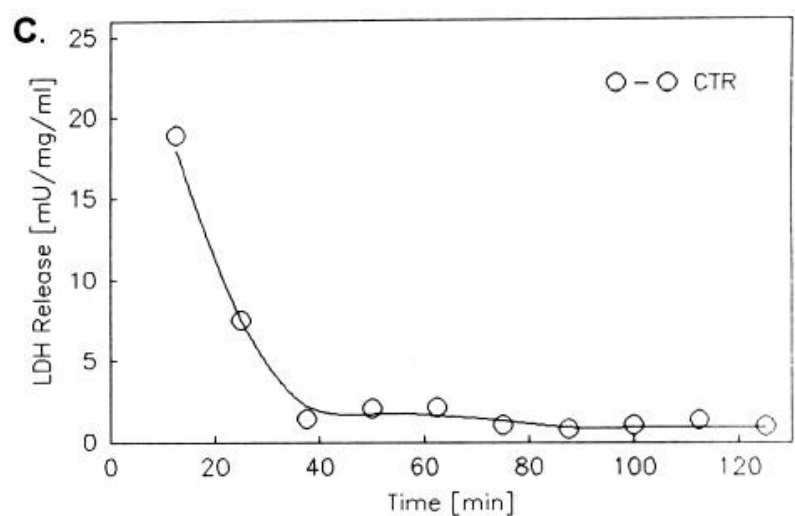

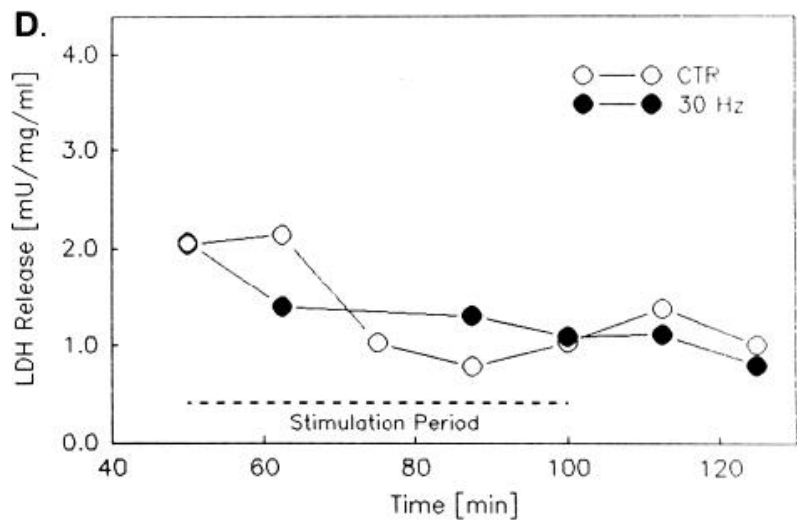

Figure 4. Protein release from rat brain slices. A, The effect of stimulation on total protein release was assayed by Coomassie blue staining of the SDS polyacrylamide gel after electrophoresis of total proteins recovered from the superfusion medium. Proteins loaded were normalized to total slice protein per chamber. $B$, NCAM was detected at high levels in slices after the stimulation period but was undetectable in the superfusion media. $C$, The release of LDH from hippocampal slices was assayed in aliquots of superfusion media collected in 12 min intervals beginning immediately after slices were placed in the chambers. Data are from one typical experiment, and each point represents a $12 \mathrm{~min}$ collection interval. $D$, LDH release assayed during the stimulation period (i.e., after $50 \mathrm{~min}$ of equilibration) was not affected by stimulation. The stimulation interval is indicated by the dashed line. Data are from a typical experiment, and represent a $12 \mathrm{~min}$ collection period.

\section{Secreted APP lacks an intact $C$-terminus}

An antiserum directed against the C-terminus of APP (Fig. 5A) reacted strongly with protein extracts from brain slices, demonstrating the presence of full length APP in these extracts (Fig. $5 A$, lane 10); however, it failed to react with APPs in the superfusion media (Fig. 5A, lanes 8 and 9). The APP derivative detected by an $\mathrm{N}$-terminal antibody, $22 \mathrm{C} 11$, in superfusion fluids was approximately $10 \mathrm{kD}$ smaller in molecular mass than that from homogenates of brain slices (Fig. 5A, lanes $1-5$ vs lanes 6 and 7), suggesting that the APP derivatives secreted from the brain slices lacked the C-terminus of full length APP. Importantly, samples collected during the initial $12 \mathrm{~min}$ of the equilibration period contained very large amounts of APPs but no detectable quantities of full-length APP (Fig. 6B).

We attempted to assay the release of $A \beta$ from cortical slices to assess whether enhanced $A P P^{s}$ secretion could alter $A \beta$ processing and release. $A \beta$ was undetectable with the R1280 antibody against Western blots of reconstituted superfusate proteins using 12\% Tris-tricine gels (Schagger and von Jagow, 1987). To determine whether this was due to our method of concentrating the superfusate proteins, we used a number of different protocols (i.e., organic extraction, salt precipitation, blotting, and elution from PVDF membranes, and dialysis through low molecular weight cut-off membranes). In no case could we detect a signal in samples that were not spiked with exogenous $A \beta$. These re- sults suggest that $A \beta$ secretion was extremely low and below the detection limit of our assay system. To test this hypothesis, slices from an entire rat cortex were placed in a single chamber and superfused. The medium from the equilibration period was collected because it contains the highest amounts of protein (cells injured from the slice procedure die and release their cytoplasmic contents during this period). In this case, a very faint $A \beta$ signal was observed on Western blots of reconstituted superfusate proteins.

To determine whether derivatives of the APP-like protein (APLP) family also were secreted from braiin slices into the superfusion media, Western blots were probed with D2-I, a polyclonal antiserum that specifically detects APLP-2 (Thinakaran and Sisodia, 1994). D2-I detected significant amounts of immunoreactive material in the expected molecular mass range that was doubled by electrical stimulation (115 $\pm 35 \%$ of basal levels, $p<0.05$ ) (Fig. $5 B$, lane 5). The selective Ml agonist WAL 2014 also increased the immunoreactivity detected with this antibody (Fig. 5B, lanes 1-4). The antibodies Alz 90 (Weidermann et al., 1989) and R1736 directed against the human forms of APP did not immunoreact with proteins in either brain slices or superfusion media. The antiserum R1736 has a very low affinity for rat brain APP, probably because the region of human APP to which it was raised differs by three amino acids from the corresponding region of rat $\mathrm{APP}$. $\mathrm{Alz} 90$ also failed to detect 
A.
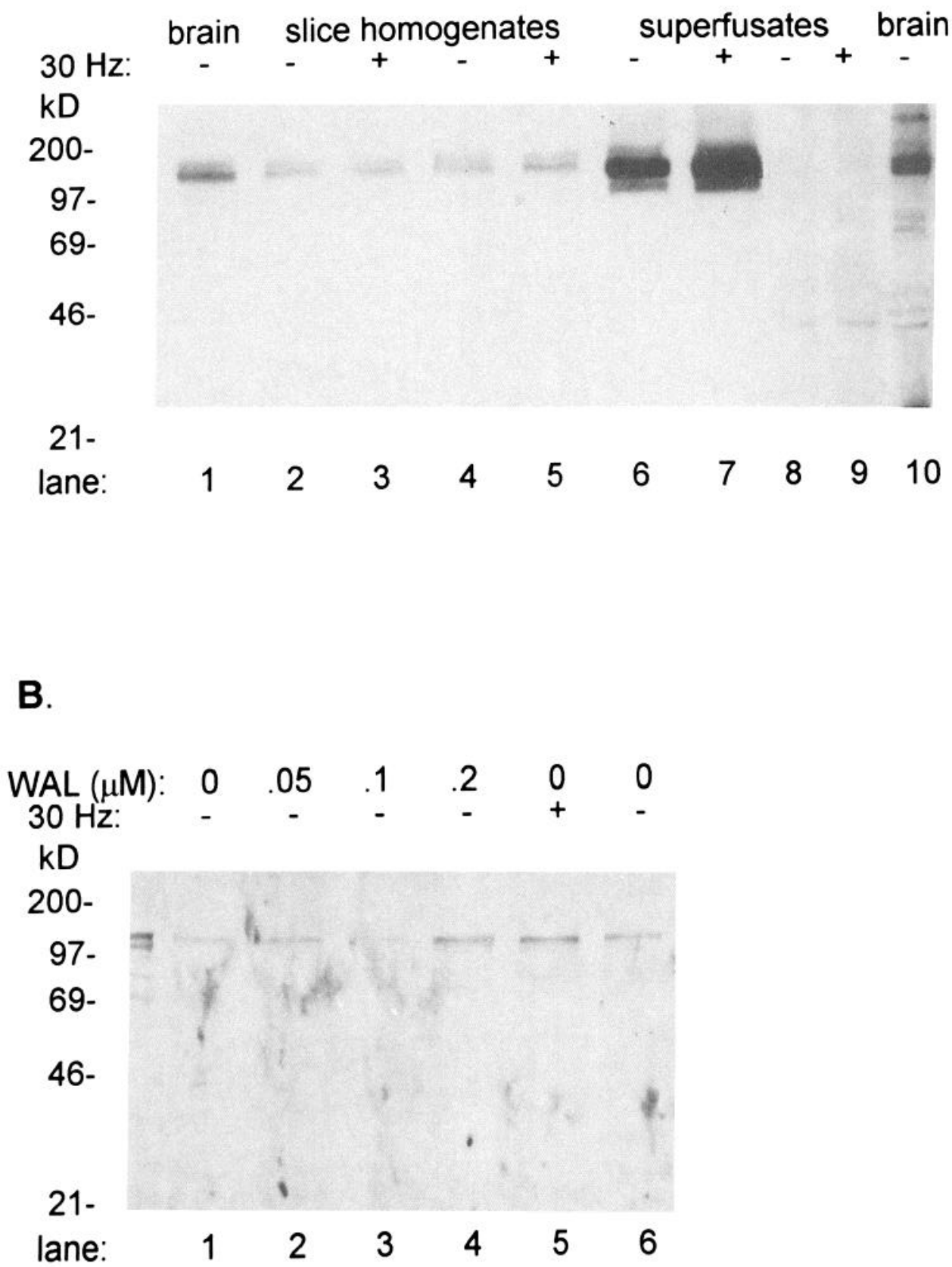

Figure 5. Secreted APP lacks an intact C-terminus and is associated with increased APLP-2 release. A, Western blot of full-length APP probed with the $22 \mathrm{Cl1}$ antibody in protein extracts from fresh rat brain (lane I), hippocampal slices (lanes 2-5), and secreted APP from the superfusion media of hippocampal slices (lanes 6 and 7). Molecular mass of released APP is approximately $10 \mathrm{kD}$ lower than slice-associated full-length APP. Lanes 8-10 were probed with an antibody raised against the $\mathrm{C}$-terminus (a-C8) and revealed full-length APP in brain extract (lane 10) but not in secreted APP (lanes 9 and 10). B, Western blot of APLP2 probed with the D2-I antibody in slice protein extracts (left of lane I) and superfusate proteins from cortical slices (lanes 1-6) proteins in superfusion media, possibly because it generates a weaker signal (approximately 1/6) than $22 \mathrm{C} 11$ and higher nonspecific background. Despite several modifications to our membrane blocking protocols, we were unable to reduce this background.

Like LDH, considerable APPs was released during the initial period following slice preparation, but this release decreased rapidly to low baseline levels (Fig. $6 A, C$ ). The stimulation-induced increase in APP secretion was maintained over a $38 \mathrm{~min}$ period and then decreased during the last $12 \mathrm{~min}$ of the stimulation interval (Fig. $6 D$ ). In light of these observations, we reduced the stimulation period of subsequent experiments to 20 $\mathrm{min}$ and lengthened the equilibration period to $75 \mathrm{~min}$. The longer equilibration period resulted in lower basal levels of APPs in the superfusion media, presumably by more effectively removing the APPs released during the tissue preparation. This change in experimental design also significantly lowered the variance between parallel superfusion chambers.

\section{$A P P^{s}$ release and overall slice PI turnover are dissociated}

To determine whether depolarization-dependent APPs release is paralleled by increases in PI breakdown, we measured PI turnover in control and stimulated cortical slices. Slices were isotopically labeled for $30 \mathrm{~min}$ with ${ }^{3} \mathrm{H}$-myo-inositol in the absence of calcium, washed, incubated in a nonradioactive medium, and exposed to lithium $(10 \mathrm{~mm})$ and carbachol $(5 \mathrm{~mm})$ or to electrical stimulation. As before, APPs release was enhanced by electrical depolarization but not by carbachol (Fig. $7 A$ ). In contrast, PI 
A.

[min]

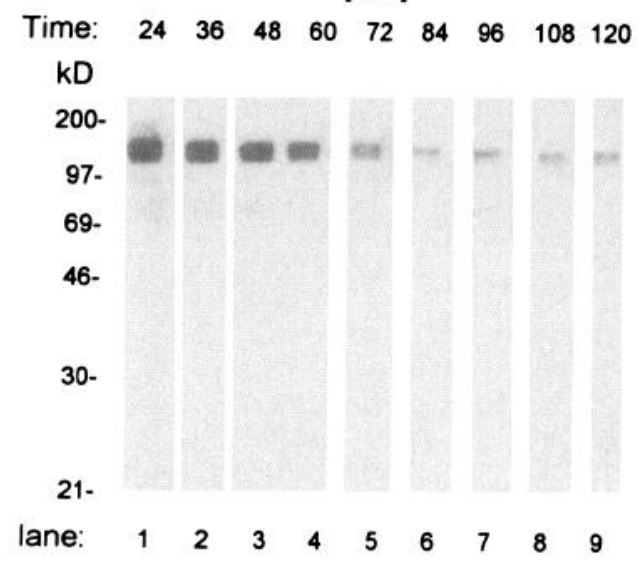

B.

[min]

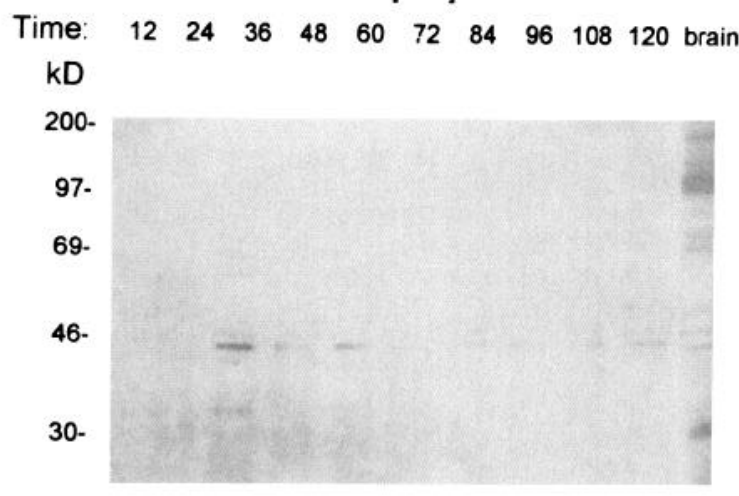

c.

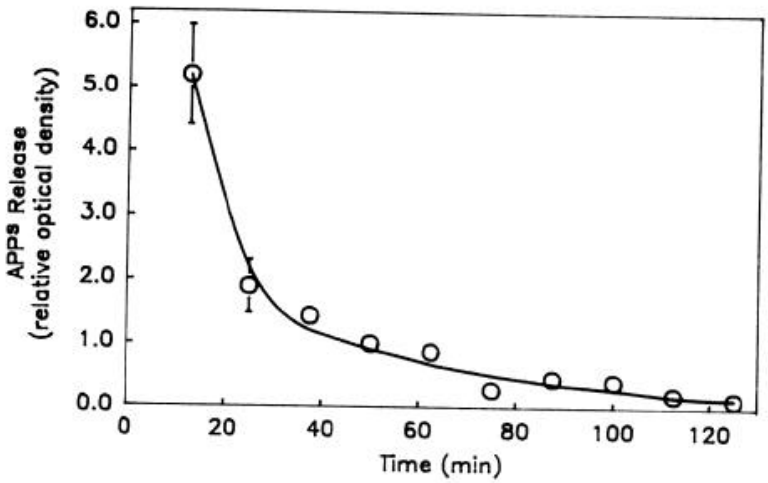

D.

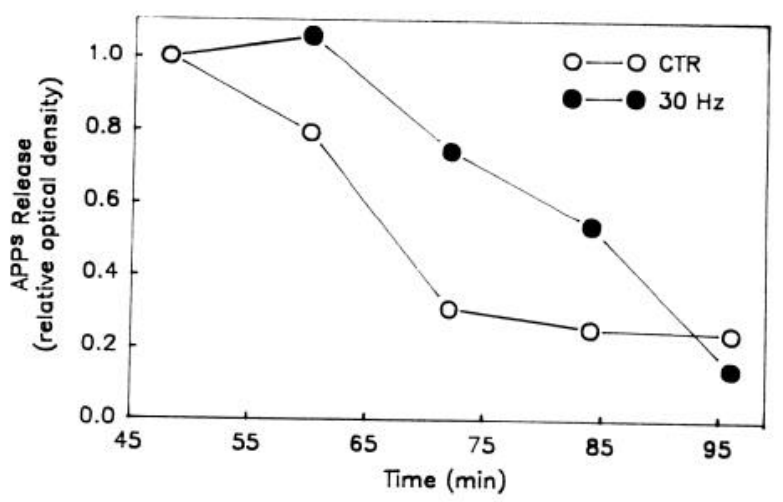

lane:

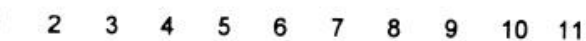

Figure 6. APP secretion from hippocampal slices is high in the initial equilibration period and stabilizes after 1 hr. A, Western blot of secreted $\mathrm{N}$-terminal APP derivatives (22C11) collected over $12 \mathrm{~min}$ intervals from superfusion media. The first time point at 12 min was overexposed (due to high APP levels) and not shown. B, Western blot of secreted proteins probed with an antiserum against the APP C-terminus (a-C8) failed to detect full-length APP in superfusion media at any time interval, including the first 12 min, suggesting that the N-terminal APP derivatives shown in $A$ are, in fact, APP. $C$, Quantitation of APP secretion over the entire experimental period, without electrical stimulation. Each point represents collection periods of $12 \mathrm{~min}$, and a mean of three to five experiments \pm SEM if larger than symbol. $D$, Time course of APP' secretion from basal (open circles) and stimulated (filled circles) hippocampal slices over the entire 50 min stimulation period. Data were collected over 12 min intervals and were normalized to basal release after a $50 \mathrm{~min}$ equilibration period. Data shown are from one typical experiment.

turnover was increased by carbachol (from $2600 \pm 180$ to 4040 $\pm 210 \mathrm{DPM} / \mathrm{mg}, p<0.01)$, but not by electrical stimulation (Fig. $7 B$ ). Glutamate release was increased by electrical depolarization (from $1.02 \pm 0.27$ to $10.75 \pm 3.14 \mathrm{nmol} / \mathrm{mg} / \mathrm{hr}, p<$ 0.05 ) but not by carbachol (Fig. $7 C$ ).

\section{Discussion}

Proteolytic processing of APP in mammalian brain includes regulated cleavage and secretion of large $\mathrm{N}$-terminal derivatives. The results of this study show that secretory processing of APP in brain slices can be affected by neuronal depolarization as well as by pharmacological stimulation of certain neurotransmitter receptors. Specifically, stimulation of the $\mathrm{ml} / \mathrm{m} 3$ subgroup of muscarinic acetylcholine receptors accelerated the secretion of C-terminally truncated, N-terminal derivatives of APP. Similar secreted polypeptides are also present in human cerebrospinal fluid (Nitsch et al., 1995) and in cell culture supernatants (Weidemann et al., 1989; Slunt et al., 1994). Brain APLP2 probably shares with APP the ability to have its processing affected by electrical stimulation and muscarinic activation, since both treatments also increased the amounts of a $110 \mathrm{kDa}$ secreted form of APLP2 detected by the APLP2-specific antiserum D2-I (Fig. $5 B$ ). Similar secreted products were observed in conditioned media obtained from a $\mathrm{N}_{2} \mathrm{~A}$ neuroblastoma line (Slunt et al., 1994). The absence of glycosaminoglycan-modified APLP2 with higher molecular masses (Thinkakaran and Sisodia, 1994) suggests that APLP2 secreted from brain slices is not modified by the addition of chondroitin sulfate proteoglycan chains, or, alternatively, that the modified form was lost during our concentration protocol.

We have previously shown that electrical depolarization of rat hippocampal slices increases APP' release, and that this effect is blocked by tetrodotoxin (Nitsch et al., 1993). We now show that this increase is partially mediated by muscarinic neurotransmission, since atropine $(1 \mu \mathrm{M})$ a nonspecific muscarinic antagonist, reduced it by approximately $75 \%$ (Fig. $2 A$ ). Electrical depolarization concurrently enhanced the release of both acetyl- 

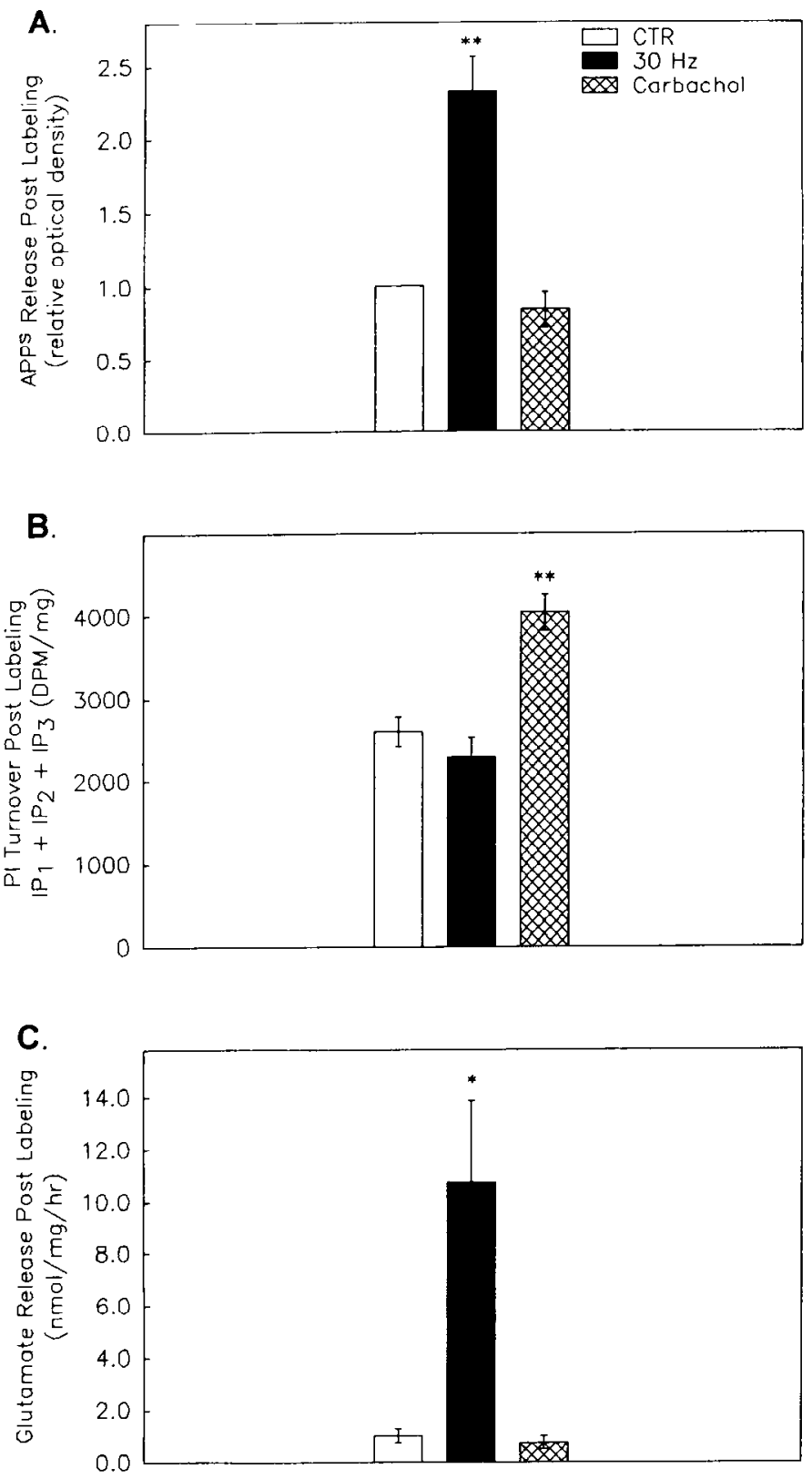

Figure 7. Comparison of APP secretion to PI turnover and glutamate release. Cortical slices were preincubated for $30 \mathrm{~min}$, pulse labeled with $5 \mu \mathrm{Ci}$ 'H-myo-inositol for $30 \mathrm{~min}$ at low extracellular calcium, washed for $15 \mathrm{~min}$, and chased for $20 \mathrm{~min}$ in the presence of lithium (10 mM) and the absence of inositol. Secreted APP and glutamate were measured in the superfusion media. Labeled inositol phosphates were measured in aqueous extracts of brain slices. A, Electrical stimulation but not carbachol $(5 \mathrm{mM})$ increased APP' release. Bars represent means \pm SEM of four experiments. ${ }^{*} p<0.01$ versus unstimulated control. B, Carbachol, but not electrical stimulation increased PI turnover cortical slices. Bars represent means \pm SEM of four experiments. ${ }^{*} p<0.05 . C$, Glutamate release was increased by electrical stimulation but not by carbachol. Means \pm SEM of four experiments. ${ }^{*} p<0.05$.

choline and glutamate (Fig. 3), another neurotransmitter capable of receptor-mediated enhancement of APPs secretion (Lee and Wurtman, 1995).

Activation of $\mathrm{ml} / \mathrm{m} 3$ muscarinic receptors with the predominately $\mathrm{m} 1$ agonist WAL 2014 (Enzinger et al., 1993) caused a dose-dependent increase in basal APP' secretion from cortical tissue slices (Fig. $2 B$ ). Its maximal effect was attained at $1 \mu \mathrm{M}$; larger doses produced progressively smaller effects, and at concentrations greater than $70 \mu \mathrm{M}$, the drug was ineffective. The biphasic response to WAL 2014 may reflect unspecific stimulation by the drug of M2-receptors at higher concentrations (Ensinger et al., 1993). In agreement with this interpretation, inhibition of $\mathrm{M} 2$ receptors with gallamine increased APP" secretion both under control conditions and, more so, when coadministered with the nonspccific muscarinic agonist carbachol (Fig. $2 A$ ). In the absence of the $\mathrm{M} 2$ receptor blocker, carbachol alone failed to stimulate APP release from hippocampal or cortical slices over a broad range of concentrations (Fig. $2 C$ ), suggesting that $\mathrm{M} 2$ receptors supress the stimulation by $\mathrm{ml} / \mathrm{m} 3$ receptors of APP' secretion. Transfected cells coexpressing both $\mathrm{ml}$ and $\mathrm{m} 2$ receptors might be useful for investigating this possibility. The ability of gallamine to increase basal APP release may be mediated by blockade of inhibitory $\mathrm{M} 2$ receptors, which are activated by basal $\mathrm{ACh}$ release.

Electrical depolarization of slices from all regions studied (i.e., hippocampus, cortex, striatum, and cerebellum) increased APP release (Fig. 1), suggesting that electrical depolarization affects APP processing throughout the CNS, probably mediated by many types of cell surface receptors.

Release of the cytoplasmic marker enzyme LDH was high during the initial $30 \mathrm{~min}$ of the equilibration period that followed the slice preparation (Fig. $4 C$ ), probably reflecting its loss from severed cells close to the slice surface (Misgeld and Froetscher, 1982). Therefore, an equilibration period preceding experiments was necessary to allow for the clearance of cellular debris. A steady baseline in LDH levels was attained after 40-50 min of superfusion under standard conditions (Fig. 4C); this remained constant during the subsequent 100 min period when stimulation experiments were performed. Electrical depolarization did not alter basal LDH release (Fig. 4D), suggesting that the structural integrity of brain cells was preserved during depolarization. Likewise, total protein release was unaffected by electrical stimulation, as indicated by unchanged amounts of superfusate proteins on Coomassie-stained SDS polyacrylamide gels (Fig. 4A). Thus, it appears that only certain proteins, like APP and APLP2 (Fig. 5), are affected by neuronal depolarization. Another related brain polypeptide, N-CAM, was present in brain protein extracts but undetectable in superfusion media from either unstimulated control or stimulated slices (Fig. $4 B$ ). To exclude the possibility that N-CAM was lost during the ultrafiltration protocol (i.e., by binding to the dialysis tubing), we concentrated N-CAM by dotblotting on PVDF (Immobilon-P, Waters) and subsequent elution. This protocol also generated undetectable levels of N-CAM in superfusion media.

Samples concentrated from media collected during the first 12 min of the incuhation period contained extremely high levels of APP،, as revealed by $22 \mathrm{C} 11$ immunoreactivity on Western blots, yet no signal was detected using the $\alpha-\mathrm{C} 8$ antibody raised against the C-terminus (Fig. $5 A$ and Fig. $6 B$ ). In contrast, this antiserum was able to detect full-length APP in protein extracts obtained from the same slices. This suggests that the APP* released during the initial equilibration period was derived from cleavage of APP holoprotein.

$\mathrm{m} 1$ and $\mathrm{m} 3$ muscarinic receptors are expressed throughout the cholinergic target regions of both the hippocampus and the cerebral cortex (Bonner et al., 1987; Wall et al., 1991a,b). These receptors are members of a large family whose members are coupled to phospholipase activation and thereby to breakdown of phospholipids including PI (Peralta et al., 1988). Cell culture 
studies have shown that APPs secretion is enhanced by treatments that increse PI turnover and thus activate protein kinases (Buxbaum et al., 1990, 1992; Nitsch et al., 1992; Slack et al., 1995) As expected, PI turnover was enhanced in slices exposed to carbachol; however, it was not affected by electrical depolarization. These findings suggest that either stimulation of PI breakdown is not coupled to the regulation of APPs secretion in brain slices, or that most of the PI turnover induced by carbachol occurs in cells that do not release APPs. This apparent discrepancy could also reflect regulation of APP processing by a different second-messenger pathway in vivo. Slack et al. (1995) has shown that tyrosine phosphorylation can also mediate APP processing in cultured cells, suggesting a potential alternative to PI mediated signaling. Additionally, it is also possible that electrical depolarization causes a large increase in PI breakdown products in a small population of neurons, which contribute relatively little to the total concentration of inositol phosphates in the slice preparation. Further experiments using preparations of homogenous cell types are needed to explore these possibilities.

The coupling of APP processing and APP release to neuronal activity suggests that treatments that modify brain neurotransmission to alter brain APPs secretion might also affect the rate of amyloid formation.

\section{References}

Behl C, Davis JB, Lesley R, Schubert D (1994) Hydrogen peroxide mediates amyloid beta protein toxicity. Cell 77:817-827.

Bonner TI, Buckley NJ, Young AC, Brann MR (1987) Identification of a family of muscarinic acetylcholine receptor genes. Science 237 527-532.

Busciglio J, Gabuzda DH, Matsudaira P, Yankner BA (1993) Generation of beta-amyloid in the secretory pathway in neuronal and nonneuronal cells. Proc Natl Acad Sci USA 90:2092-2096.

Buxbaum JD, Gandy SE, Cicchetti P. Ehrlich ME, Czernik AJ, Fracasso RP, Ramabhadran TV, Unterbeck AJ, Greengard P (1990) Processing of Alzheimer beta/A4 amyloid precursor protein: modulation by agents that regulate protein phosphorylation. Proc Natl Acad Sci USA 87:6003-6006

Buxbaum JD, Oishi M, Chen HI, Pinkas-Kramarski R, Jaffe EA, Gandy SE, Greengard P (1992) Cholinergic agonists and interleukin 1 regulate processing and secretion of the Alzheimer beta/A4 amyloid protein precursor. Proc Natl Acad Sci USA 89:10075-10078.

Buxbaum JD, Koo EH, Grenngard P (1993) Protein phosphorylation inhibits production of Alzheimer amyloid b/A4 peptide. Proc Natl Acad Sci USA 90:9195-9198.

Ensinger HA, Doods HN, Immel-Sehr AR, Kuhn FJ, Lambrecht G, Mendla KD, Müller RE, Mutschler E, Sagrada A, Walther G, Hammer R (1993) WAL 2014-a muscarinic agonist with preferential neuron-stimulating properties. Life Sci 52:473-480.

Esch FS, Keim PS, Beattie EC, Blacher RW, Culwell AR, Oltersdorf T, McClure D, Ward, PJ (1990) Cleavage of amyloid beta peptide during constitutive processing of its precursor. Science 248:11221124.

Gabuzda D, Busciglio J, Yankner BA (1993) Inhibition of beta-amyloid production by activation of protein kinase C. J Neurochem, 61:23262329.

Games D, Adams D, Alessandrini R, Barbour R, Berthelette P, Blackwell C, Carr T, Clemens J, Donaldson T, Gillespie F, Guido T, Hagopian S, Johnson-Wood K, Khan K, Lee M, Leibowitz, Lieberburg I, Little S, Masliah E, McConlogue L, Montoya-Zavala M, Mucke L, Paganini L, Penniman E, Power M, Schenk D, Seubert P, Snyder B. Soriano F, Tan H, Vitale J, Wadsworth S, Wolozin B, Zhao J (1995) Alzheimer-type neuropathology in transgenic mice overexpressing V717F b-amyloid precursor protein. Nature 373:523-527.

Haass C, Schlossmacher MG, Hung AY, Vigo-Pelfrey C, Mellon A, Ostaszewski BL, Lieberburg I, Koo EH, Schenk D, Teplow DB, Selkoe DJ (1992) Amyloid b-protein is produced by cultured cells during normal metabolism. Nature 359:322-325.

Hung AY, Haass C, Nitsch RM, Qiu WQ, Citron M, Wurtman RJ, Growdon JH Selkoe DJ (1993) Activation of protein kinase C in- hibits cellular production of the amyloid beta-protein. $J$ Biol Chem 268: 22959-22962

Jessell TM (1988) Adhesion molecules and the hierarchy of neural development. Neuron 1:3-13.

Kang J, Lemaire HG, Unterbeck A, Salbaum JM, Masters CL, Grzeschik KH, Multhaup G, Beyreuther K, Muiller-Hill B (1987) The precursor of Alzheimer's disease amyloid A4 protein resembles a cellsurface receptor. Nature 325:733-736.

Kitaguchi N, Takahashi Y, Tokushima Y, Shiojiri S, Ito H (1988) Novel precursor of Alzheimer's disease amyloid protein shows protease inhibitory activity. Nature 331:530-532.

Koh JY, Choi DW (1987) Quantitative determination of glutamate mlediated cortical neuronal injury in cell culture by lactate dehydrogenase efflux assay. J Neurosci Methods 20:83-90.

Koo EH, Park L, Selkoe DJ (1993) Amyloid beta-protein as a substrate interacts with extracellular matrix to promote neurite outgrowth. Proc Natl Acad Sci USA 90:4748-4752.

Lee R, Wurtman RJ (1995) Amyloid precursor protein processing is stimulated by metabotropic glutamate receptors. Proc Natl Acad Sci USA, in press.

Mattson MP, Cheng B, Culwell AR, Esch FS, Lieberburg I, Rydel RE (1993) Evidence for excitoprotective and intraneuronal calcium-regulating roles for secreted forms of the beta-amyloid precursor protein. Neuron 10:243-254.

Milward EA, Papadopoulos R, Fuller SJ, Moir RD, Small D, Beyreuther $K$, Masters CL (1992) The amyloid protein precursor of Alzheimer's disease is a mediator of the effects of nerve growth factor on neurite outgrowth. Neuron 9:129-137.

Misgeld U, Frotscher M (1982) Dependence of the viability of neurons in hippocampal slices on oxygen supply. Brain Res Bull 8:95-100.

Mucke L, Masliah E, Johnson WB, Ruppe MD, Alford M, Rockenstein EM, Forss-Petter S, Pietropaolo M, Mallory M, Abraham CR (1994) Synaptotrophic effects of human amyloid $b$ protein precursor in the cortex of transgenic mice. Brain Res 666:151-167.

Müller U, Cristina N, Li Z-W, Wolfer DP, Lipp H-P, R licke T, Brandner $S$, Aguzzi A, Weissmann C (1994) Behavioral and anatomical deficits in mice homozygous for a modified b-annyloid precursor protein gene. Cell 79:755-765.

Nitsch RM, Slack BE, Wurtman RJ, Growdon JH (1992) Release of Alzheimer amyloid precursor derivatives stimulated by activation of muscarinic acetylcholine receptors. Science 258:304-307.

Nitsch RM, Farber SA, Growdon JH, Wurtman RJ (1993) Release of amyloid beta-protein precursor derivatives by electrical depolarization of rat hippocampal slices. Proc Natl Acad Sci USA 90:51915193

Nitsch RM, Rebeck GW, Deng M, Richardson UI, Tennis M, Schenk D, Vigo-Pelfrey C, Lieberburg I, Wurtman RJ, Hyman BT, Growdon JH (1995) Cerebrospinal fluid levels of amyloid b-protein in Alzheimer's disease: inverse correlation with severity of dementia and effect of ApoE genotype. Ann Neurol 37:512-518.

Olney JW, Price MT, Fuller TA, Labruyere J, Samson L, Carpenter M, Mahan K (1986) The anti-excitotoxic effects of certain anesthetics, analgesics and sedative-hypnotics. Neurosei Lett 68:29-34.

Peralta EG, Ashkenazi JW, Winslow J, Ramachandran J, Capon DJ (1988) Differential regulation of PI hydrolysis and adenylyl cyclase by muscarinic receptor subtypes. Nature 334:434-437.

Podlisny MB, Tolan D, Selkoe DJ (1991) Homology of the amyloid beta protein precursor in monkey and human supports a primate model for beta amyloidosis in Alzheimer's disease. Am J Pathol 138 $1423-1435$.

Ponte P, Gonzalez-DeWhitt P, Schilling J, Miller J, Hsu D, Greenberg B, Davis K, Wallace W, Lieberburg I, Fuller F (1988) A new A4 amyloid mRNA contains a domain homologous to serine proteinase inhibitors. Nature 331:525-527.

Schagger H, von Jagow G (1987) Tricine-sodium dodecyl sulfate-polyacrylamide gel electrophoresis for the separation of proteins in the range from 1 to $100 \mathrm{kDA}$. Anal Biochem 166:368-379.

Schubert D, Jin LW, Saitoh T, Cole G (1989) The regulation of amyloid beta protein precursor secretion and its modulatory role in cell adhesion. Neuron 3:689-694.

Selkoe DJ (1994) Alzheimer's disease: a central role for amyloid. J Neuropathol Exp Neurol 53:429-437.

Selkoe DJ, Berman Podlisny M, Joachim CL, Vickers EA, Lee G, Frit/ LC, Oltersdorf T (1988) b-Amyloid precursor protein of Alzheimer's disease occurs as 110- to 135-kilodalton membrane-associated pro- 
teins in neural and nonneural tissues. Proc Natl Acad Sci USA 85: $7341-7345$.

Seubert P, Oltersdorf T, Lee MG, Barbour R, Blomquist C, Davis DL, Bryant K, Fritz LC, Galasko, Thal LJ, Lieberburg I, Schenk DB (1993) Secretion of b-amyloid precursor oprotein cleaved at the amino terminus of the b-amyloid peptide. Nature 361:260-263.

Sinha S, Knops J, Esch F, Moyer ED, Oltersdorf T (1991) Conversion of the Alzheimer's beta-amyloid precursor protein (APP) Kunitz domain into a potent human neutrophil elastase inhibitor. J Biol Chem 266:21011-21013.

Sisodia SS (1992) Beta-amyloid precursor protein cleavage by a membrane-bound protease. Proc Natl Acad Sci USA 89:6075-60;9.

Sisodia SS, Koo EH, Beyreuther K, Unterbeck A, Price DL (1990) Evidence that beta-amyloid protein in Alzheimer's disease is not derived by normal processing. Science 248:492-495.

Slack BE, Nitsch RM, Livneh E, Kunz GM Jr, Breu J, Eldar H, Wurtman RJ (1993) Regulation by phorbol esters of amyloid precursor protein release from Swiss $3 \mathrm{~T} 3$ fibroblasts overexpressing protein $\mathbf{k i}-$ nase Ca. J Biol Chem 268:21097-21101.

Slack BE, Breu J, Petryniak MA, Srivastava KS, Wurtman RJ (1995) Tyrosine phosporylation-dependent stimulation of amyloid precursor protein secretion by the $\mathrm{m} 3$ muscarinic acetylcholine receptor. J Biol Chem 270:8337-9344.

Slunt HH, Thinakaran G, von Koch C, Lo ACY, Tanzi RE, Sisodia SS (1994) Expression of a ubiquitous, cross reactive homologue of the mouse b-amyloid precursor protein (APP). J Biol Chem 269:26372644.

Tanzi RE, Gusella JF, Watkins PC, Bruns GA, St George-Hyslop P, Van Keuren ML, Patterson D, Pagan S, Kurnit DM, Neve RL (1987)
Amyloid beta protein gene: cDNA mRNA distribution and genetic linkage near the Alzheimer locus. Science 235:880-884.

Thinakaran G, Sisodia SS (1994) Amyloid precursor-like protein 2 (AP-LP2) is modified by the addition of chondroitin sulfate glycosaminoglycan at a single site. J Biol Chem 269:22099-22104.

Van Nostrand WE, Schmaier AH, Farrow JS, Cunningham DD (1990) Protease nexin-II (amyloid beta-protein precursor): a platelet alphagranule protein Science 248:745-748.

Wall SJ, Yasuda RP, Hory F, Flagg S, Martin BM, Ginns EI, Wolfe BB (1991a) Production of antisera selective for $\mathrm{ml}$ muscarinic receptors using fusion proteins: distribution of $\mathrm{ml}$ receptors in rat brain. Mol Pharmacol 39:643-649.

Wall SJ, Yasuda RP, Li M, Wolfe BB (1991b) Development of an antiserum against $m 3$ muscarinic receptors: distribution of $m 3$ receptors in rat tissues and clonal cell lines. Mol Pharmacol 40:783-789.

Wasco W, Bupp K, Magendanz M, Gusella JF, Tanzi RE, Solomon F (1992) Identification of a mouse brain cDNA that encodes a protein related to the Alzhcimcr's disease-associated amyloid b-protein precursor. Proc Natl Acad Sci USA 89:10758-10762.

Wasco W, Gurubhagavatula S, Paradis MD, Romano DM, Sisodia SS, Hyman BT, Neve RL, Tanzi RE (1993) Isolation and characterization of APLP2 encoding a homologue of the Alzheimer's associated amyloid b protein precursor. Nat Genet 5:95-99.

Weidemann A, König G, Bunke D, Fischer P, Salbaum JM, Masters CL Beyreuther K (1989) Identification, biogenesis, and localization of precursors of Alzheimer's disease A4 amyloid protein. Cell 57:115 126

Zheng H, Jiang M, Trumbauer ME, Hopkins R, Sirinathsinghji DJS, Stevens KA, Conner MW, Slunt HH, Sisodia SS, Chen HY, Von der Ploeg LHT (1995) Mice deficient for the amyloid precursor protein gene. Ann NY Acad Sci, in press. 